\title{
ESL Writing Self-Efficacy: Contribution to ESL Writing Skills Development
}

\author{
Ilyana Jalaluddin ${ }^{1, \text { A *, Hamidah Yamat }}{ }^{2, \text { B, And }}$ \\ Melor Md Yunus 3 , C \\ ${ }^{I}$ Faculty of Modern Language, Universiti Putra Malaysia \\ ${ }^{2,3}$ Faculty of Education, National University of Malaysia
}

\begin{abstract}
This case study aims to understand how writing self-efficacy level contributes to the development of learners' writing skills. The participants of this study consist of three form four learners and their English teacher. Here, teacher's assistance would act as the mechanism to develop the learners' writing self-efficacy. In order to gather information on teacher's assistance, learners' writing skills and writing self-efficacy, various types of data were collected: observation, questionnaire and interview. Though this research on self-efficacy and writing is not a new area in educational research, the findings still can be the added to the existing body of knowledge. Based on the finding derived from this study, two theoretical implications are discussed in this paper. The first part of theoretical implication centred on the reciprocal relationship of cognitive and behavioural engagement. Then the second part discussed the inclusion of teacher's assistance component to the self-efficacy framework. Both of these implications had become the additional components to the existing framework which was proposed by Linnenbrink and Pintrich (2003).

Keywords: Writing self-efficacy, writing skills, teacher's assistance
\end{abstract}

Submitted Date 20 June 2013

Accepted Date: 25 June 2013

\section{Introduction}

The role of self-efficacy has received extensive support from a growing body of findings from diverse fields in the United States for meta-analysis of research on the relationship between self-efficacy and academic outcomes. Flower and Hayes (1990)'s concept of the process approach in writing has shown that efficacy is one of the motivational factors in determining progress in writing.

In the past, there were many quantitative researches focusing on the relationship between self-efficacy and writing. One of it was Pajares and colleagues who had used a lot of correlational studies to show the relationship between self-efficacy and academic achievement. Pajares and Johnson (1995) had used path analysis to test the influence of writing self-efficacy, self-concept, apprehension, and aptitude on the essay writing performance of 181 ninth-grade learners in a public high school in the southwestern of the United States.

The researchers were especially interested in whether self-efficacy beliefs would make an independent contribution to the prediction of writing performance. There was a strong relationship between self-efficacy and performance (.60). Self-concept scores ranged from 15 to 78 with a mean of 49, or 4.9 on the 8-point Likert scale, indicating that a positive self-concept statement was "more true than false". Overall, results from this study showed that learners' self-efficacy perceptions were strong predictors of their writing performance and played mediational role as hypothesized by social cognitive theory.

Results from Pajares and Valiante (1997) investigation were also contrasted with those obtained by Pajares and Johnson (1995), who investigated the writing self-efficacy of high school learners. Pajares and Johnson (1995) reported that ninth grade boys and girls did not differ in writing performance, but the boys reported higher self-efficacy. Pajares and Valiante (1997) also found no differences in performance, but the fifth-grade girls in their study reported higher self-efficacy and lower apprehension and they perceived writing as more useful. Findings from this study strengthen Bandura (1986)'s claim that self-efficacy plays an influential role in human agency. In addition, the contrast of these results with those of Pajares and Johnson (1995) suggests that there may be a developmental component to the creation and evolution of writing selfefficacy and that the predictive and mediational roles of self-efficacy may differ depending on the academic level and years of schooling.

In Malaysia, a research on the relationship between learners' self-efficacy and their English language achievement had been conducted by Rahil Mahyuddin, Habibah Elias, Loh Sau Cheong, Muhd Fauzi Muhamad, Nooreen Noordin and Maria Chong Abdullah (2006). This descriptive-correlational study was conducted on 1,146 learners from eight secondary schools in the Petaling district, Selangor. The instruments used to measure self-efficacy were the Self-efficacy Scale developed by Bandura (1995) and the Self-efficacy Scale developed 
by Kim and Park (1997). The findings showed that $51 \%$ of learners had high self-efficacy while $48 \%$ showed low self-efficacy. Rahil Mahyuddin et al. (2006) found that $43.6 \%$ of the learners are Malays who believed that English was difficult and they did not understand the language. Thus, they were not motivated to learn or use the language. Besides this, Rahil Mahyuddin et al. (2006) also considered the number of learners with low selfefficacy as large considering the school being the second school in the state last year examination. From the results, it showed that the learners' self-efficacy declined as they advanced through the school because of less teachers' attention. According to Rahil Mahyuddin et al. (2006:65), "Form Four is the year sandwiched between two important public examinations, hence teacher concentration on these learners is less". This local research in the way portrays the importance of teacher's assistance in writing process.

Nevertheless, few researches had focused on teacher's modelling and motivation in L2 learning. In other researches done in L1 context had found that teacher's modelling and motivation actually guided learners in carrying out the task given more efficiently. For instance, Schunk and Swartz (1993) as cited in Schunk and Zimmerman (2007) found that modelled strategy instructions by the teacher combined with goal setting enhanced elementary children's writing skills and self-efficacy and helped them maintain and transfer use of the strategy beyond the instructional context. In the research, average-ability and gifted learners received instructions on writing paragraphs over 20 sessions that included five sessions each on descriptive, informative, narrative story, and narrative descriptive paragraphs. Learners were taught a process strategy: choose a topic to write about, write down ideas about the topic, pick the main idea, plan the paragraphs, and write down the main idea and the other sentences. The teacher modelled and explained the strategy, after which the learners received guided and independent practice. At the start of each session, some learners received a learning process goal where the teacher advised them to try to use the strategy to write paragraphs and in between, feedback was also given by the teacher. Other children received a product (outcome) goal where the teacher told them to try to write paragraphs and they were advised to work productively. Across average and gifted learners, process-goalplus-feedback learners generally outperformed product-goal children on writing self-efficacy and writing achievement, and demonstrated the greatest strategy use. These results suggest that modelling, practice, and feedback, combined with learning goals and evaluations of strategy effectiveness, moved children to a selfcontrolled level, higher self-efficacy, and thus, better performance.

In other study, Zimmerman and Kitsantas (2002) found that the mastery model also improved writing self-efficacy and writing skills more than the no-model condition. Feedback also led to gain in self-efficacy and revision skills. These results suggested that the benefits of the coping model may have stemmed from the information conveyed about error corrections, which help moved the learners from the observational to emulative levels (Zimmerman \& Kitsantas, 2002). Witnessing a flawless performance like in the mastery modelling did not convey the same type of information as the coping model. According to Zimmerman and Kitsanta (2002:665), "the benefits of feedback may derive from its capacity to help learners to learn and move to the self-controlled and self-regulated levels". In other words, it can effectively teach learners self-regulatory skills and raise their self-efficacy for applying them (Zimmerman \& Kitsanta, 2002). According to Schunk and Zimmerman (2003), based on the findings of the research, it shows that learners require modelled instructions and practice on adapting the strategy for use on different tasks in order to move beyond the first level of skills development. Linnenbrink and Pintrich (2003:131) further indicated that "attempted tasks slightly beyond one's current level are important for continued learning and improvement, as is reflected by Vygotsky's notion of the zone of proximal development".

Based on the researches discussed above, it can be seen that teacher actually influence the development of learners' motivation and skills in learning. This is further supported by Isaacson (2004) who pointed out that learners' achievement in writing is linked to teaching practices such as providing frequent opportunities to write, and focusing on the writing process. Jarvela (2001) also had pointed out that what learners intend to do in the classroom, how they perceive their ability, and what they actually can do to achieve these goals depend largely on how they appraise various learning situations such as teacher's approach. Based on the argument above, learners obviously need support from teachers in developing positive self-beliefs in writing which finally can help in improving their writing skills. Self-belief, or more specifically 'self-efficacy', is also important here because it "influences the course of action people choose to pursue, how much effort they put forth in given endeavours" (Bandura, 1997:3). In other words, one's self-efficacy can affect how one behaves, thoughts and emotional reactions in achievement settings. With teacher's assistance, it might help to boost writers' selfefficacy and finally to fine tune skills in writing. This is because "self-efficacious individuals are more willing to participate, to work harder, and persist longer in tasks and have less adverse reactions when encountering difficulties than those who doubt their capabilities" (Hidi \& Pietro, 2008:148). Thus, it is important to investigate the role of the teacher in the writing process as well, as "the teachers who do not feel efficacious in the writing domain lack the ability to model good writing, a necessary skill in the development of the learners writing" (Pajares, 2003:3). 
Nevertheless, there are limited local researches (L2 context) available about how teacher's assistance affects rural area learners' writing self-efficacy and skills in writing. Even though local studies on self-efficacy perspectives in the education field are available, most research focuses on teachers' self-efficacy in schools (Zuraidah, 1999; Chew, 2000), learners' self-efficacy in learning Mathematics and Sciences in English (Wong, 2001; Wong, 2004) and also the relationship between academic self-efficacy and motivation, self-esteem and self-regulation (Norzilah, 2005; Rosna, 1999; Mohamed Abdirrahman, 2004; Noorlizawati, 2007). The findings of studies conducted elsewhere in different cultural and educational context (such as Pajares \& Johnson 1995; Pajares 1996; Pajares \& Valiante 2008) meanwhile, cannot be generalised to the local situation as writing selfefficacy is believed to be situation-specific and domain-specific, and the level of writing self-efficacy has been found vary depending on the educational context, for example teaching practices, facilities provided. Thus, Volet (2001) posited that as motivation and self-beliefs are domain-specific, studies should not simply compare the cognitive, affective or motivational characteristics of groups of learners from different countries or ethnic groups and do not identify the aspect of culture. Since there is a difference in motivation and beliefs across the culture, it is therefore important to explore and identify the relationship between teacher's assistance and writing self-efficacy in the local setting. Overall, this study attempts to analyse in-depth (through observation, interviews and questionnaire) how teacher's assistance affects rural learners' writing self-efficacy and writing skills.

\section{The Process Of Collecting Data}

Both quantitative and qualitative approaches are adopted in order to obtain a more holistic view of the research issues. Meanwhile the case study method is employed in order to facilitate a more in-depth probe into the matter. The first objective of this study is to investigate the level of rural area learners' writing self-efficacy and writing proficiency. The writing proficiency level was thus evaluated based on the holistic marking scheme as prescribed by the Malaysian Examination Syndicate of the Education Ministry and school-based assessment. Meanwhile, learners' writing self-efficacy was evaluated using the writing self-efficacy scale adapted from

Bottomley, Henk and Melnick (1998). Both provided the researcher with the descriptive statistics such as mean and overall scores which described the level of the learners' writing self-efficacy and proficiency level. The second objective of this study is to identify teacher's assistance and how it affects learners' writing skills and writing self-efficacy. Thus, a qualitative approach was adopted in this study. Here, this study placed a heavy emphasis on the perceptions and actions of Form Four learners and teacher through classroom observations, and interviews with the learners and teacher. By having classroom observation and interviews, it allowed the researcher to assess the participants' unobservable (such as feelings) and observable behaviour which were used in the language tasks. Classroom observation was used in this study to further explain teacher's assistance in the writing classroom. In addition, it was used to explain the phenomenon of writing self-efficacy which was obtained from the WSE questionnaire earlier.

Learners' behaviour which was associated with the self-efficacy in writing was observed twice a week. This study adopted non-participant classroom observation for analysing self-efficacy to understand the participants' self-efficacy phenomena in their learning to write. A detail report which includes the learners' action and dialogues was recorded to show an interpretive description of their behaviour which was associated with writing self-efficacy. According to Wang and Pape (2007), evidence of the learners' self-efficacy beliefs can be obtained based on three characteristics: persistence in accomplishing language tasks, self-awareness of English proficiency, and willingness to engage in language activities. These characteristics which were used by Wang and Pape (2007) were based on Bandura's (1997) concept of self-efficacy. The descriptions for each category can be summarised as in Table 1 below:

TABLE 1 Wang and Pape (2007) description in observing learners' behaviour associated with self-efficacy in writing.

\begin{tabular}{|l|l|}
\hline Categories & Description \\
\hline $\begin{array}{l}\text { 1. Persistence in } \\
\text { accomplishing writing } \\
\text { tasks }\end{array}$ & $\begin{array}{l}\text { Learners persisted longer in the activities that they believed they could do well on, but gave up } \\
\text { easily or avoided performing tasks that they could not do very well. This proved to be a clue } \\
\text { that their persistence in accomplishing the writing tasks might be an indicator of their self- } \\
\text { beliefs }\end{array}$ \\
\hline $\begin{array}{l}\text { 2. Self-awareness of } \\
\text { English proficiency }\end{array}$ & $\begin{array}{l}\text { Learners' awareness of their English proficiency also known as perceived competence. When } \\
\text { learners show lack of competence in performing writing tasks, they are categorised as low } \\
\text { efficacy writers. For example, a learner who is unable to retell a story as he has limited } \\
\text { vocabulary (unable to explain in English). This can be further confirmed through an interview } \\
\text { asking him to give reasons for not being able to retell the story. }\end{array}$ \\
\hline $\begin{array}{l}\text { 3. Willingness to engage } \\
\text { in language activities }\end{array}$ & $\begin{array}{l}\text { Learners show different levels of willingness to participate in writing tasks. A classroom } \\
\text { observation can provide evidence for a relationship between learners' self-efficacy and their } \\
\text { willingness to participate For example, an observation showed that a learner was quite a } \\
\text { passive participant in the classroom. When asked for reason during an interview, the learner } \\
\text { admits that he could not answer and was concerned with his classmate's responses to his } \\
\text { answers. }\end{array}$ \\
\hline
\end{tabular}


The researcher used these categories when coding the data for the learners' behaviour associated with self-efficacy in writing. Meanwhile, the interviews with the learners and teacher were used to describe the rationale of support given, and the learners' writing self-efficacy level. Indirectly, the combination of the qualitative and quantitative approaches here can help to confirm or cross validate relationship discovered between the variables, as "when quantitative and qualitative methods can be compared to see if they converged on a single interpretation of a phenomenon" (Gardner 2009:558).

\section{Participants In This Study}

The research was carried out in one of rural secondary schools in Malaysia. The school namely Angsana Secondary School (pseudonym) is one of the biggest rural secondary schools in Hilir Perak (North part of Malaysia). It had a total of 70 teaching staffs and more than a thousand learners. Based on the Angsana Secondary School Data Unit (2008), there are only two Chinese teachers and the rest are Malay teachers. Out of the nine teachers teaching English, only seven are TESL-trained. The school also has an enrolment of 1,256 learners, all of whom are Malays except for 43 "orang Asli" (Aborigines) learners. Most of them come from the average socio-economic background. Their parents are mainly farmers, labourers and odd-job workers. Since all of them are from non-English speaking homes, their command of the language is very low. This school is one of the schools which achieved the lowest percentage in English in major district examination (Angsana Secondary School Data Unit 2007). Based on the report by SMK Angsana English Panel (2007), the strong influence of the learners' first language or rather their mother tongue has been a hindrance to the teaching and learning of English. Their attitude towards English is that of a foreign language. Learners prefer translation in Malay language and most of the teachers have to mix Malay and English when teaching. These learners and teachers' background in the way "present a web of social relations, a variety of activities, and diverse background which provides richer and more interesting data" (Neuman 2003:371). For the purpose of this study, one class that was Form Form learners were chosen randomly. These students were 16 years old and their class was the best class among Form Four classes. In this paper, three students out of 30 in the class namely Farah (the highest selfefficacy writer), Haslina (average self-efficacy writer) and Aishah (the lowest self-efficacy writer) will be discussed.

\section{The Writing Process In This Study}

A total of eight essays consisting of first and second draft were written during this data collection period. Two drafts were written for each essay. As such, the process of producing one essay, took more than one lesson. In general, the writing process of each essay took more than a double period (1 hour) and the lesson continued the week after that which was also a double period class. For the purpose of this paper, Essay 2 entitled 'My Father' will be discussed in detail in this paper. The following sections illustrate the overall process of writing the following four essays.

In the first week of the lesson, the teacher's focus was more on the learners' content. At this stage, she preferred to ask questions first to elicit more ideas from the learners rather than her giving all the ideas to the learners. Each learner would contribute an idea for the given topic and based on the learners' responses, the teacher would probe more questions to help them expand their ideas. Thus, the questions would finally lead to a class discussion where all the learners were involved to give their opinion. Overall, this question-answer process took about 15 to 20 minutes. After the learners finished listing their rough ideas, the teacher would give 30 to 40 minutes for them to write their first draft and submitted it. They were allowed to discuss with their peers as well to develop their ideas. This portrays more of the writing stage in a writing process as pointed out by Siti Hamim Stapa (1998) who terms this stage as the act of producing the first draft or drafting.

After marking and checking the learners' first drafts, the teacher would return them a week later which would be the second week of the lesson. Upon receiving their first draft, the teacher assisted the learners in three ways: giving clues, comments, and suggestions. Firstly, the teacher assisted them by giving clues or guided information such as Malay words or examples that portrayed the learners' real life situation. This had helped the learners in this study to find the suitable words to convey their meaning clearer. However, if the learners were unable to develop their writing with the clues given, the teacher would also give suggestions to them. The suggestions given were in detail where the sentences were underlined and numbered accordingly to indicate the errors. At this stage as well, the teacher started to focus on the language aspect. Here, the teacher would provide the written comments in their first draft and also the verbal comments. The verbal comments were delivered in class during the editing activity called 'sentence surgery'. For the activity, the teacher would prepare a handout consisting of a list of incorrect sentences which were taken from the learners' first draft. The teacher distributed the handout and asked the learners to identify the language errors in each sentence. Based on the learners' responses, the teacher would comment their sentences. This 'sentence surgery' process normally took about 30 minutes. In short, this exercise is the process of editing and revising the learners' sentences in the first draft. 
Thus, this portrays more of the writing stage in a process-based approach. As Earl and Zimmerman (2003) point out that the writing stage of a writing process includes the editing and revising stages.

After the sentence surgery exercise, the learners would write their second draft for about 30 to 35 minutes. While they were working on their second draft either in group or individually, the teacher monitored their progress closely. The teacher would sit with the weak learners and observed how they wrote their second draft. When the particular learners made errors, the teacher would ask questions or explain to them their mistakes. At this stage, the teacher focused on their vocabulary and content development. Through the face-toface discussion, the particular learners were able to ask questions regarding the written comments that they received in their first draft. The teacher then explained and also gave suggestions on how to rectify the errors. This portrayed the teacher-learner writing conference style where the teacher had brief discussions with the writers for the purpose of helping them while the task was still in progress. In addition, this portrayed the writing stage where the learners were still in the process of revising and editing their first draft, and trying to produce their second draft based on the comments they received in the first draft. After the second draft was completed, the learners then submitted it to the teacher and she would provide the marks or grade. This portrayed more of the post-writing stage where the writers despatched their writing to the readers and from here, they received the reader's responses.

Overall, throughout the process, the learners were able to produce two drafts after going through the process of brainstorming, drafting, editing and revising before publishing it for the teacher to read. In addition, the teacher provided assistance throughout the process of writing by focusing on the ideas or content first and gradually built their language aspect through discussions after the first draft had been produced. This depicted the writing process approach as suggested by Duke (1983), Siti Hamim Stapa (1998), and Earl and Zimmerman (2003). Throughout the process as well, there were five main assistances provided by the teacher that can be identified - asking questions, giving comments, giving suggestions, and clues as well as providing individual discussions. Here, teacher's assistance can be briefly summarised and presented in Figure 1 which was adapted from a diagram by Earle and Zimmerman (2002).

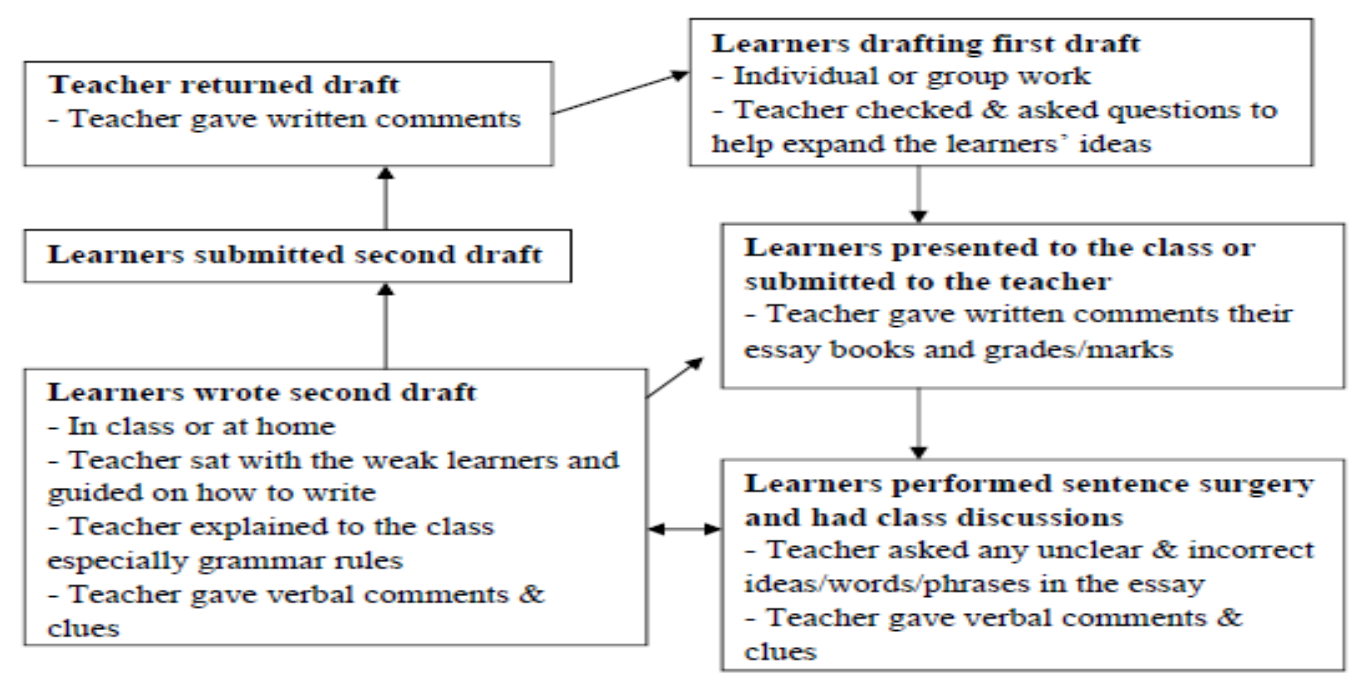

Figure 1 The writing process in this study

Based on Figure 1 above, it shows that the teacher created a prototypical element of writing process which involved drafting, editing and rewriting. In doing so, the teacher was able to question, and give comments to get clarification and elaboration from the learners systematically and indirectly help to improve their draft consequently. In sum, with this intervention, it is thus important to see how teacher's assistance affects the learners' writing skills. This will be further discussed in the next section on teacher's assistance in developing the learners' writing skills and self-efficacy.

\section{Finding 1: Teacher's Assistance Via Writing Process Approach And Its Effect On Rural Learners' Writing Skills}

In this study, it can be seen that the interaction with the teacher was able to show the participants how readers would react to their writing. In addition, it showed the participants the fallacy of assuming too much in writing and the need to provide more detail, or where they were being repetitious of ideas and get off the track. This finally led to the changes in the learners' drafts by including suggestions or comments proposed by the 
teacher during the discussion. Changes could be seen in terms of words and elaboration in the second draft throughout the learning process until the compositions were produced.

Firstly, the teacher's questions of who, what, when and how helped the learners to find the appropriate words to express their ideas. The three participants changed their inaccurate vocabulary in the first draft to the correct words after the teacher questioned the meaning that they were trying to convey. This can be seen a lot in Farah's essay where she managed to find the appropriate words to express her ideas in her Essay 2 and she made many changes in Essay 2 compared to the other two writers. Here, the teacher's questions and verbal comments prompted Farah to identify the right choice of words and added more descriptions to further elaborate her ideas.

Firstly, Farah's choice of words became more specific when the teacher questioned the meaning of the words in her first draft. For example, in her first Essay 2 draft, she wrote "My father has many people in family and he had grown in the farmer family" (Sentence 6). When the teacher pointed out that the word "family" was more specific and clearer in meaning than the word "people", she then knew that the word "people" is general.

She narrowed it down by changing the sentence to "My father has many siblings in his family" for her final draft. Even though she suggested "big family" during the class discussion on 15 July 2009, she used the word "siblings" in her final draft. This showed that she finally understood the word "people" was too general and should be related to the term "family".

Besides changing to more specific words, the teacher's questions and comments had assisted Farah in choosing more suitable words that explained the intended meaning. For example, she rectified her sentence in Essay 2 by changing the word "weird" in her sentence 5 "He also has weird and moustache" (first draft). This was after the teacher pointed out that the sentence was incomplete because Farah used the adjective "weird" but not modifying any noun (observation on 8 July 2009). The teacher then assisted her by raising the question of "Do you mean the noun janggut or adjective weird?" (observation on 15 July 2009). From here, Farah then explained to the teacher that she was referring to the short janggut. The teacher then gave a clue that the word started with "g" (observation on 15 July 2009). In her final draft, Farah managed to change to a clearer sentence that is "He has a goatee and moustache". This implied that the question and clues posed by the teacher managed to indicate the vagueness and finally clarify the meaning that the writer tried to convey. This is because when questioned by the teacher, it guided Farah to a more specific vocabulary that elaborated more of the physical characteristics of her father.

During the discussion of Essay 2 as well, the teacher informed Farah that her sentence 9 "My father did not ever sigh to be the useful people in the future" (first draft) was "hanging" (observation on 15 July 2009) and "wrong sentence structure" (observation on 8 July 2009). In addition, the teacher wrote a comment "What do you mean?" for her sentence 9. Other learners then suggested to her to add "man" after the word "useful" to complete the sentence and replaced the word "people" (observation on 15 July 2009). Nevertheless, in her final draft of Essay 2, Farah still retained her original idea and repeated the same mistake by using "man" after the word "poor", and "people" after the adjective "useful". In her second draft, she wrote "Although my father is poorman before, but he want to be a useful people in his future" (second draft). Though the grammar mistakes were repeated in the final draft, the meaning was clearer compared to the original sentence "Although my father is a poor man, but my father did not ever sigh to be the useful people in the future" (first draft). In her second draft, she explained the reason why his father "did not ever sight to be the useful people in the future" (first draft). By adding the new sentence "Although my father is poorman before" in her second draft, it indirectly gave the impression of what happened before that led to her father's strong determination to be a better man in the future. Thus, this made the sentence complete rather than hanging. This implied that teacher's assistance of soliciting meaning from Farah via questions and comments triggered her reconsider the meaning of her sentence even though her language errors still persisted.

Overall, from Farah's essay, it can be seen that she preferred to replace her words in her first draft which were too general to more specific words when the teacher commented that the ideas were general and the meaning was ambiguous. This was different from Haslina, the average self-efficacy writer as she preferred to delete words or phrases that the teacher commented as vague or did not make sense, and later added new ideas to the sentences. Thus, it made the sentences shorter and direct to the point rather than going around the circle. For instance, she made changes in her Essay 2 by deleting illogical phrases and elaborating the sentences by adding new ideas. Firstly, Haslina removed part of her sentences in the second draft of Essay 2 when the sentences were questioned by the teacher in terms of the meaning that she was trying to convey. During the prewriting stage, Haslina received very specific written comments on her first draft which specified that her sentence $3,5,7,11,12,14$ and 15 "were topsy-turvy" and "didn't make sense" ( 8 July 2009). Nevertheless, the teacher gave suggestions for correction in sentence 3, 5, 12 and 14 as shown below: 
TABLE 2 Suggestions for the sentences in Haslina's first draft (Essay 2).

\begin{tabular}{|l|l|l|}
\hline $\begin{array}{l}\text { Sentence } \\
\text { No. }\end{array}$ & First draft & Suggestion by the teacher \\
\hline 3 & $\begin{array}{l}\text { My father not a rich people. But my } \\
\text { father never let his children in a } \\
\text { difficult life. }\end{array}$ & $\begin{array}{l}\text { My father is not rich, but he would never } \\
\text { let his children live in difficult life. }\end{array}$ \\
\hline 5 & My father like do a joke with all of us. & My father likes to joke with us. \\
\hline 12 & I'm still remember until now. & I could still remember his advice. \\
\hline 14 & My father is someone a fair. & My father is a fair person \\
\hline
\end{tabular}

Haslina followed her teacher's suggestions in the second draft except for sentence 3 where she deleted it. For sentence 7, 11 and 15, the teacher only posed questions and wrote comments that guided Haslina for further improvement. The teacher commented that her sentence 7 "He also always give a poser" was unclear and the teacher questioned the meaning of the word 'poser'. In addition, the teacher pointed out that sentence 11 "Father say no bequest can father inheritor to you but just knowledge only bequest which precious to you and just who have a high knowledge people will see" was difficult to be understood and raised the question of "What do you mean? Do you mean to say that your father puts great importance in education?". Later, the teacher showed sentence 7 and 11 to the class and asked the class to correct them (observation on 15 July 2009). Through the discussion, Haslina received the suggestion "there's nothing precious than knowledge" to replace her original sentence 11. However, she decided to cancel sentence 7 and 11 in her final draft. As a result, her final draft was shorter than her first draft after she omitted the two long sentences.

Next, Haslina also wrote "My father also never to overindulge to us because he wants us to learn how to be self-sufficient" (sentence 16) in her first draft of Essay 1. The teacher then underlined the phrase "to overindulge to us" (first draft) and questioned "What do you mean? Are you trying to say that your father "never want to shower his children with material wealth?"'(observation on 8 July 2009). Even though the teacher did suggest a sentence here to replace her old sentence, she shortened her sentence to make it simpler. Haslina changed sentence 16 to "My father also hopes his children learn how to be self-sufficient". Here, it showed that she deleted the phrase "to overindulge to us" and wrote a simple and logical sentence to explain that his father did not "shower her with wealth" but "wanted her to accept everything with open heart" (observation on 8 July 2009). This is actually similar to sentence 7 and 11 where Haslina also cancelled part of sentence 16 when the teacher categorised it as unclear or "topsy-turvy". This implied that the teacher's questions made her realize that sentence 7, 11 and 16 were vague and could not be understood by the teacher and friends. This perhaps led her to delete these three sentences to avoid ambiguity.

Besides deleting the ambiguous sentences, Haslina also made changes to other sentences to convey her ideas clearer. In her first draft of Essay 2, the teacher commented that sentence 8 "My father also always gives me advise about the lesson" (first draft) was unclear. The teacher argued "the lesson? What lesson?" in her first draft to indicate that sentence 8 was vague (observation on 8 July 2009). Thus, in her second draft, she made a general statement without specifying the type of advice that her father gave her. Haslina changed the sentence to "He also always gives me advise about anything" (second draft). Here, it shows that the phrase "...about the lesson" (first draft) was changed to "...about anything" (second draft) which generalised the type of advice that her father gave. Indirectly, Haslina was reacting to the teacher's question to clarify her ideas for sentence 8 where the question of "what" managed to make Haslina further elaborate her stand. Haslina also rephrased her sentence 15 after the teacher asked "What are you trying to say?" in her first draft (observation on 8 July 2009). In her first draft, she wrote "Which the wrong will accept a sentence, whenever which not wrong will get an avenge" (sentence 15). However, in her second draft, she tried to rephrase it to:

But sometimes when my father is angry with me, I cry. I feel that father never leave me because he always angry with me. But I know, my father scolds me because he wants me to be disciplined. (Second draft)

Based on the excerpt above, Haslina explained what she meant by "accept a sentence" (first draft) and "get an avenge" (first draft) by relating to the concept of "angry" (second draft) and "disciplined" (second draft).

In her second draft, she specifically mentioned what her father would do wrong by writing "my father is angry with me" (second draft) rather than using vicious words like "sentence" and "avenge". In addition, Haslina also explained why "the father is angry with her" (second draft) to rationalize her father's action that is to "disciplined" (second draft) her. In comparison to the first draft, she did not state any reason why her father "give her sentence and avenge" (first draft). Sentence 15 was a fragment that was without any subject as she began the sentence with "Which the wrong will accept a sentence or avenge" (first draft). In her second draft however, she mentioned clearly the doer or the subject as "My father". Thus, this makes the sentences in the second draft clearer than the first draft. Overall, Haslina's second draft was shorter than the first draft and consisted of many simple sentences. In comparison to her first draft, she tended to write many compound and long sentences. Nevertheless, when the teacher questioned her the meaning of a sentence, she would either 
rephrased it to a simple sentence like sentence 8 and 15 , or deleted it such as sentence 7,11 and 16. This implies that teacher's questions on meaning had her doubt her own ideas and she chose to delete them to avoid the ambiguity.

In general, Farah and Haslina's writing indicates changes when more assistances were given. Here, the learners' writing development in this study can thus be illustrated in Fig 2 below:

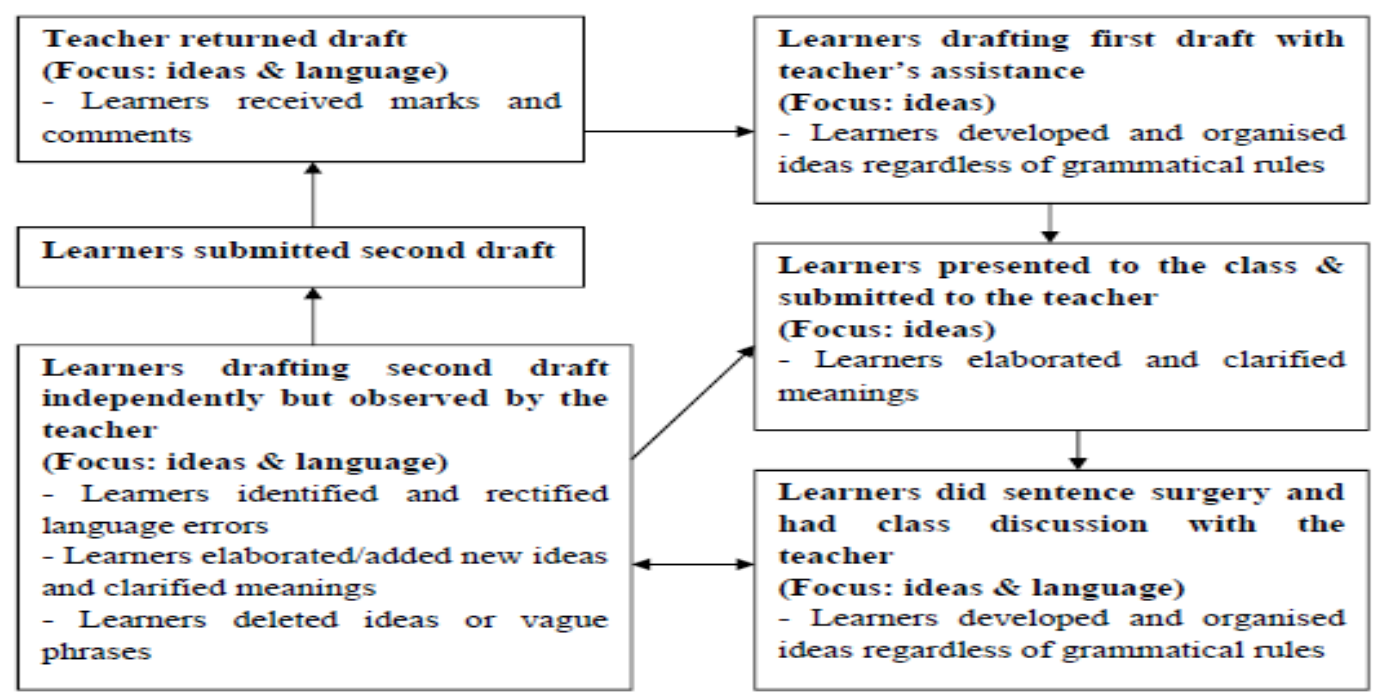

FIGURE 2 The writing development of the three participants in this study

Changes in the learners' writing after given assistance as shown above indirectly depicted the zone of proximal development (ZPD) stages proposed by Vygotsky where learners move from dependent learners (where they need assistance) and gradually become independent towards the end when they are able to conceptualise and understand the meaning behind the activities. In this study, the teacher's questioning and feedback had the learners changed their idea presentation when they realised their ideas were not clearly understood by readers. In both Farah and Haslina's cases, the teacher did not give any direct answer to clear up their ambiguous ideas, but the teacher only gave indications of what were the errors and the reasons why they were wrong. Based on the feedback, both learners independently tried to improve their writing by changing and deleting certain words which they initially believed able to convey their intended ideas. This process indirectly showed the movement from stage 1 (where assistance provided by more capable others), stage II (where the learners tried to assist themselves) to stage III (internalisation took place) of the ZPD model. Thus, it showed the teacher's assistance of questioning and commenting was actually able to gradually move the high and average self-efficacy writers throughout the process of writing to independent writers. As McCarthey, et al. (2004:353) has pointed out that "when the teacher and learners developed intersubjectivity, the learners were more likely to internalise the classroom discourse and use it in writing".

However, when too much assistance was provided, learners will not be able to internalise and perform independently towards the end. This is because it leads to the changes of drafts only by using the teacher's input. Though the learners in this study were able to write second draft without errors, there was no transfer of knowledge and skills in writing, but only lifting from the teacher's words. This can be seen in Aishah's composition where she relied heavily on the teacher's written suggestions and followed strictly the suggestions given. Even though there was a comment given which required her to elaborate certain sentences in her first draft (Observation, 8 July 2009), she ignored it and opted for only written suggestion given. Thus, there was no new idea development in her second draft in comparison to her peers Farah and Haslina, who improved their ideas development and language aspect. This can be seen in Essay 2 where she only made changes in her sentences after the teacher underlined eight sentences in her first draft and indicated them as unclear as shown in Table 2 below: 
TABLE 2 The differences between Aishah's first and second drafts.

\begin{tabular}{|c|c|c|}
\hline Sentence No & First draft & Second draft \\
\hline 5 & $\begin{array}{l}\text { He will wears jeans trousers that had } \\
\text { torn and he will keep that trouser } \\
\text { until he can't use it. }\end{array}$ & $\begin{array}{l}\text { He will wear a pair of faded and } \\
\text { worned-out jeans and he will keep that } \\
\text { trouser until it couldn't be used } \\
\text { anymore. }\end{array}$ \\
\hline 9 & $\begin{array}{l}\text { Day until night he just did worthy } \\
\text { activities. }\end{array}$ & $\begin{array}{l}\text { He always fill up his time with worthy } \\
\text { activities. }\end{array}$ \\
\hline 13 & $\begin{array}{l}\text { Besides that, my father rarely forget } \\
\text { his liability either in religion, as } \\
\text { leader in his family or else. }\end{array}$ & $\begin{array}{l}\text { Besides that, my father never forget } \\
\text { his responsibility either in religion, as } \\
\text { leader in his family or other } \\
\text { responsibilities. }\end{array}$ \\
\hline 17 & $\begin{array}{l}\text { He told me to elevate Malay peoples } \\
\text { prestige or Muslims people. }\end{array}$ & Aishah cancelled the sentence \\
\hline 18 & $\begin{array}{l}\text { I will never forget all his advises and } \\
\text { will try to exist it. }\end{array}$ & $\begin{array}{l}\text { I will never forget all his advices and } \\
\text { will try to make it come true. }\end{array}$ \\
\hline $19 \& 21$ & $\begin{array}{l}\text { Sometimes when have time he will } \\
\text { brought his family to picnic. }\end{array}$ & $\begin{array}{l}\text { Sometimes when there is time he will } \\
\text { take his family to a picnic. }\end{array}$ \\
\hline 25 & $\begin{array}{l}\text { My father does not likes to go to Fun } \\
\text { Fair or Sureheboh. }\end{array}$ & $\begin{array}{l}\text { My father does not like to a funfair or } \\
\text { concert such as 'Sureheboh' concert. }\end{array}$ \\
\hline 26 & $\begin{array}{l}\text { The reason my father gives a lot of } \\
\text { negative things happen. }\end{array}$ & $\begin{array}{l}\text { The reason my father gives is because } \\
\text { there are lots of negative things } \\
\text { happen there. }\end{array}$ \\
\hline
\end{tabular}

In her first draft, the teacher specifically wrote comments that the eight sentences listed above (Table 2) as not well-organised and thus needed to be rephrased. Overall, Aishah did two ways to rephrase her incorrect sentences mentioned by the teacher. Firstly, she changed a lot of her vocabulary and secondly, she changed the pattern of her sentences to rephrase her incorrect sentences. For example, in sentence 5, the structure of the sentence had been changed to passive voice from "he will keep that trouser until he can't use it" (first draft) to "he will keep that trouser until it couldn't be used anymore" (second draft). Obviously, the second subject interest of "he" in sentence 5 had been changed to "it" in the second draft. Here, Aishah managed to avoid from repeating the subject "he" when she changed the second subject interest to "it". Thus, it made the meaning clearer when the object "the trouser" was emphasised and elaborated clearly. In comparison to the original sentence in the first draft, the subject "he" stood out more than the object "trouser" until the condition of the trouser was vague. The focus is more on the subject "he" who could not use the trouser anymore. However, in the second draft, the subject interest is "the trouser" that could not be used anymore which implied that the trouser was old or torn.

In conclusion, the writers were able to revise their writing based on the suggestions or comments given by the teacher. Based on the finding, it can be concluded that they made attempts to address the comments even though the revision made in response to these comments generally had; i) minimal changes; ii) led to changes with mixed effects (i.e. changed draft using the teacher's input; iii) changed drafts without the teacher's input; or iv) did not change their drafts at all although mistakes had been discussed). To be specific, the writers firstly changed their word choices or add elaboration when the teacher found unsuitable words and insufficient ideas. Secondly, the writers even changed their ideas when the reader (the teacher) questioned and did not accept their explanation. Obviously, the writers used the teacher's feedback to direct themselves to write or elaborate more. In addition, the teacher's assistance affected the way they valued and developed their voices as writers. These findings relate to the concept of internalisation by Vygotsky. In the questioning and commenting session, the readers gave feedback and evaluate the writers' writing. For example, Farah later improvised her writing by considering the teacher's example and her peers' suggestion. This implies that the writer eventually internalised the feedback from her social interaction to further improve her writing. To use Vygotsky's term, there is a shift from intrapsychological functioning (between people) to intrapsychological (within an individual mind) (Smith, 1997).

\section{Finding 2: Learners' Writing Self-Efficacy And Writing Skills Performance}

In this study, teacher's assistance affects the learners' writing self-efficacy differently. Farah who has a high writing self-efficacy was very comfortable with the teacher's questions and comments during the writing process. To her, the teacher's questions motivated her to further improve her writing and the classroom observation showed her active participation during the class discussion. When the teacher held the face-to-face discussion with her, Farah had more confident as she had the chance to discuss in detail of her writing. Meanwhile, the classroom observation showed that she posted a lot of questions during the face-to-face discussion. In addition, the teacher's comments even make her understand more and thus, she felt more 
confident to write as she knew what to do. Similarly, Haslina also feels more confident to write when the teacher asked questions as it guided her on how to complete the task better. Nevertheless, she preferred direct comments and not written comments as verbal comments would lead to the class discussion. When it became a class discussion, her confident to rectify her writing increased as she understood more and had more ideas. She admitted that she felt confident to question her friends similar to how the teacher questioned her. Nevertheless,

Aishah, who scores a low writing self-efficacy, felt uncomfortable with the teacher's questions and comments. She felt embarrassed and scared when verbal comments were given or when the teacher asked questions. As a consequence, she withdrew from the writing task as she lost her ideas and demotivated to write when the teacher directly commented her work or prompted her with further questions. However, Aishah gained more confident when the teacher only gave written comments and did not involve in any face-to-face discussion. The next paragraph will discuss in detail how different learners with different writing self-efficacy levels react to teacher's assistance.

Firstly, the teacher's verbal comments on the participants and her supports for them caused a mixed feeling between the three participants. For instance, the classroom observation showed that Farah's writing selfefficacy remained high when assistance was provided by the teacher. The high level of writing self-efficacy can be portrayed by her behaviour in the classroom as adapted from Wang and Pape's (2007) and Bandura's (1997) description of a high self-efficacy learner. During the writing process, the teacher questioned each learner to help them develop their ideas and also detect their language errors in writing. Based on the responses given by the learners, the teacher prompted more questions and thus led to class discussion where everyone tried to contribute ideas. The process of questioning continued until one written product managed to be produced. When asked during the interview, Farah expressed that "the teacher's questions made [her] more confident to elaborate [her] ideas [and enabled her to] write more" (interview on 1 July 2009). According to Farah (interview on 1 July 2009), "the teacher's questions increased [her] confidence as the teacher showed [her] errors and asked questions based on [her] errors made". By questioning, "it motivated [her] to find more ideas" [and] it would be awkward [for her] if the teacher did not ask any questions" (interview on 14 Oct 2009). Her motivation to find the correct answers could be further portrayed in the classroom observation. Throughout the five-month period, Farah showed constant active participation when the teacher probed her with questions. It was observed that she frequently raised her hand and kept trying to provide correct answers when the teacher asked questions (observation on 1 July 2009 and 14 Oct 2009). For instance, Farah raised her hand after the teacher read a sentence in front of the class (observation on 1 July 2009). She suggested the word "hope" was wrong and it should be changed to "hopes". The teacher then asked Farah to explain the reason. Farah explained that "Every learner ..." should be singular. Similarly, Farah tried to defend her answer when others questioned her response.

For instance, when a boy commented that a sentence read by the teacher was hanging, Farah raised her hand to suggest adding "people" after the word "useful" (observation on 15 July 2009). However, the boy responded that Farah's answer was wrong and should be "man" because it is singular. The teacher then asked Farah regarding her opinion on the subject "man". Farah then responded that "man is one and people is many" and finally agreed with the boy's answer.

Furthermore, whenever Farah's responses were incorrect, she tried to elaborate more and gave the reasons to defend her answers until they were approved by the teacher (observation on 1 July 2009, 16 Sept 2009, 7 Oct 2009 and 14 Oct 2009). For instance, Farah's group ended their story by stating that Thomas Wilson lost his memory after the smoke incident (observation on 16 Sept 2009). The teacher later probed the group with the question "However... what happen?". Farah stood up and responded "damage...his head". The teacher responded "yes" and Farah continued writing with the other character "Assunta". The teacher then again reminded her group to be direct and brief. Based on the teacher's response, Farah stood up again and suggested "Assunta takes care of him and the owner let him stay there". From here, the teacher kept asking questions and Farah kept giving answers on behalf of her group. The teacher asked again "stay where?" and Farah answered "behind the house". Then the teacher asked "how long?" and Farah stated "5 years". Based on Farah's answer, the teacher then asked another question again "in return what did Thomas do?" and Farah again stood up and answered "give money back". Nevertheless, the teacher informed them that the answer was wrong and asked the group to refer back to the book on the last page. Farah read her book and quickly answered "take care of the goat". The teacher then agreed and asked her group to write it on the mahjong paper. These examples supported Farah's indication that she was confident to elaborate more of her ideas as she perceived the teacher's questions as the motivation for her to write more. She only stopped when the teacher notified that her answer was correct. This portrayed her persistence to complete the writing task when questioned by the teacher.

On the other hand, the classroom observation showed that Haslina, the average writing self-efficacy writer changed depending on the assistance provided by the teacher. This was observed when the learners were unable to understand the text use for their writing. Here, the teacher used both L1 and L2. The objective was to help the learners understand the text so that they could express their ideas better. Haslina expressed her confidence to write more when the teacher used mixed language of Malay and English to guide the class. She 
admitted that "[she] felt more confident because [she] could understand better [and] knew what to do next" (interview on 9 Sept 2009). This shows that Haslina had more confident to write when the teacher translated certain words in her native language that is Malay. This is because she understood more of what she needed to write in her composition. This is further portrayed in the classroom observation where Haslina was able to identify the meaning of the words when the class was quiet when an unfamiliar word was given (observation on 9 Sept 2009). When the learners could not form a sentence to express "one needs to be patience when facing any difficulty", the teacher gave an example in the L1. Initially, the other learner, Noran tried to respond by saying "don't give up, continues again", but the teacher disagreed and pointed out that it was "something to do with grumble". Based on the teacher's explanation, the learners admitted that they did not understand by asking "what is grumble?" Thus, this prompted the teacher to give one example in Malay: "esei ko ni teruk la, apa la".

Haslina then was able to guess the meaning of the word "grumble" by responding "merungut". She finally formed a sentence "we do not easily give up and do not grumble" and agreed by the teacher. This shows that Haslina had the confident to respond to the teacher's question when none in the class admitted they knew the answer. This implies that Haslina gained the courage even though she admitted earlier that "[she] did not like to talk in front of other learners" (interview on 15 July 2009). The courageous act perhaps was due to her understanding of the explanation of the word "grumble" was given in Malay. As a consequence, she willingly provided the answer during the class discussion.

Based on Farah and Haslina's examples above, it shows that Farah's and Haslina's aspiration, activity participation were increased differently by the teacher's constant assistance throughout the writing process. Both of the learners felt confident when they received the verbal comments directly. This is because they gave them the chance to discuss and clarify their understanding even more. When they understood more about the task, they gained more confident to approach the task and persist longer. Both show willingness to participate and respond when the teacher approached them verbally. Nevertheless, the classroom observation shows that Aishah's writing self-efficacy decreased when teacher's assistance was provided. The decrease of her writing self-efficacy can be portrayed from her behaviour while engaging in the writing process. Unlike Farah and Haslina, Aishah did not prefer to receive any verbal comments from the teacher. Even though the teacher spent time and joined Aishah's discussion, Aishah did not feel comfortable and confident at all. This is because "the teacher gave direct comments [to her] to [guide her throughout] the process" (interview on 7 Oct 2009). Aishah was "embarrassed when the teacher commented [her] writing [verbally] as [she] felt as if [she] was very weak and did not know anything about writing even though she was already in form four" (interview on 7 Oct 2009). In sum, the interview indicates that Aishah could not accept the teacher's verbal comments or handled the faceto-face discussion because it demotivated her to pursue her writing task.

Her lack of confident and uneasiness were noticeable in the classroom observation. She bowed her head down (observation on 7 Oct 2009), avoided eye contacts and kept quiet (observation, 29 July 2009) were her common physical reaction upon receiving the teacher's comments. In addition, she covered her work when the teacher wanted to observe how she wrote (observation on 10 Aug 2009). For instance, the teacher pointed out that Aishah used the apostrophe "s" incorrectly in her writing when the teacher observed her writing her first draft (observation on 29 July 2009). Nevertheless, Aishah did not respond to the remark and just kept quiet. She just wrote "it's" to show belonging and thus, the teacher asked her to check again the usage of apostrophe "s".Based on the examples, it shows that Aishah interpreted the teacher's comments and questions differently from Farah and Haslina. The classroom observation indicates that she felt unsecure and demotivated. This implies that direct comments perhaps create hostility on Aishah's part because to her, it only exposed her weaknesses even more and thus lowered her confidence to pursue with the writing task. In comparison to Farah and Haslina, the teacher's comments and questions had actually supported their learning development thus boosted their confidence. Aishah admitted that "[she] preferred [her teacher] to write comment in [her] book [instead]" (interview on 7 Oct 2009). By writing comments in her book, "[she] would not feel shy and more comfortable that way" (interview on 7 Oct 2009). This shows that Aishah preferred the teacher to write comments in her book instead of verbal comments. This is perhaps because of the nature of "written comment" where she did not have to face her teacher directly and thus spared her the fear.

The different effects of assistance on the low self-efficacy writer above indicates that Aishah, the low self-efficacy writer, needed teacher's assistance but not at the same level as Farah and Haslina. This was because of her inferiority and low self-confidence in writing until she thought that she was not at the same level like her friends and her teacher looked down on her if the teacher approached her verbally or directly. These imply that the teacher's roles in assisting the learners need to be varied depending on the learners' confidence in pursuing their written tasks. In addition, it might also imply as what Beck (2006) termed as 'confusion concerning the intent of comment'. According to Beck (2006:417), "when the learners do not perceive an exclusively negative intent behind their teacher's response, they may fail to share the background knowledge that would allow them to interpret the teacher's instructive remarks as she wishes them to be interpreted, leading to exasperation and confusion concerning the intent of the comments". In other words, writers with different 
level of self-efficacy might interpret teacher's assistance differently and most of the time perceived negatively.

As a consequence, the low self-efficacy writer in this study felt intimidated with the teacher's verbal comments and questions. It only lowered her confidence in writing and made the learner unwilling to settle the task. This implies that she accepted teacher's assistance differently from her other peers who had high and average writing self-efficacy. The low self-efficacy writer's anxiety towards teacher's assistance is obviously consistent with Pajares, Johnson and Usher (2007) findings that proved only mastery experience and anxiety proved predictive of the elementary and middle schools learners' performance.

In conclusion, through the writing process the participants actually understood their task better and felt confident and motivated to carry out the task. Nevertheless, when the learners were not able to do the task or respond to the teacher during the process, they therefore make negative self-attributions of ability saying: "I can't do it!" and finally withdrew. This was depicted by the low self-efficacy writer, Aishah who gave up when the teacher pointed out her errors. Findings from this study thus strengthened Bandura's (1986) claim that selfefficacy beliefs play an influential role in human agency, and they support the work of prior researchers who reported a significant relationship between learners' sense of confidence in academic areas and their subsequent effort in these areas. A more specific framework on self-efficacy can thus be illustrated as below where it can reflect a more situational perspective of efficacy theory in comparison to the original framework by Linnenbrink and Pintrich (2003);

FIGURE 3 Self-efficacy framework based on this study

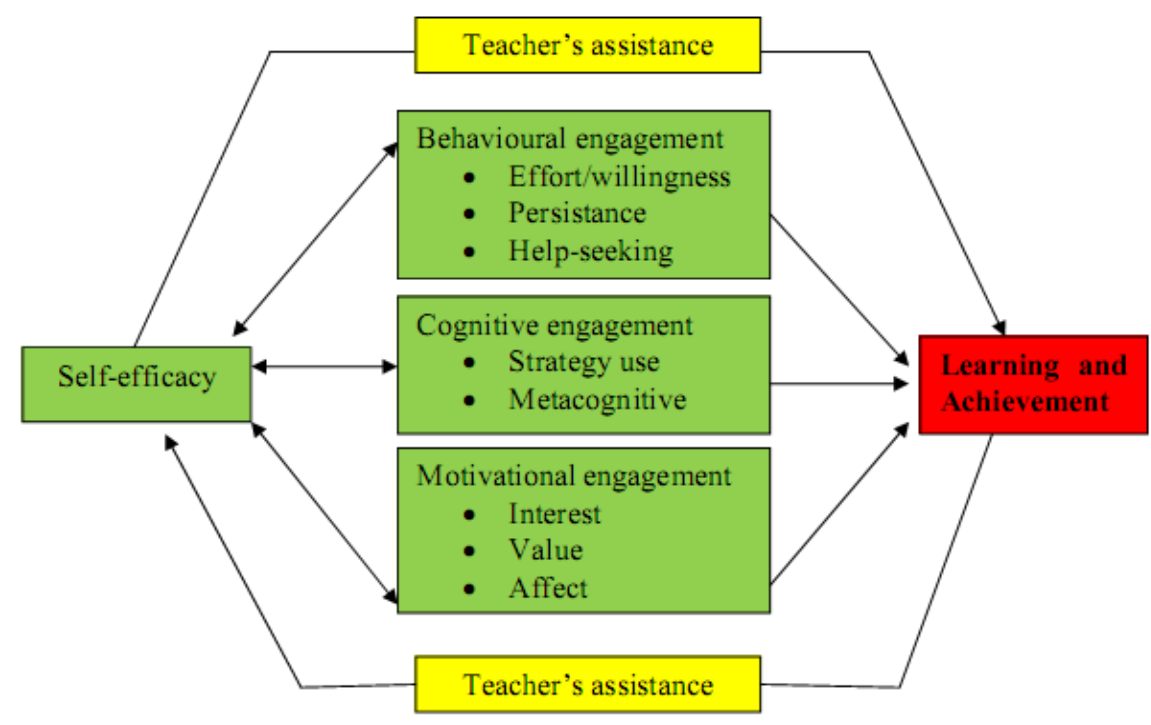

Based on Fig 3, there were two new components added which were teacher's assistance and the back flow of each component. Firstly, the arrows for the three component; behavioural engagement, cognitive engagement and, learning and achievement component flew back to self-efficacy. In comparison to the original framework (by Linnenbrink and Pintrich, 2003), the three components show a linear connection between "selfefficacy" and "learning and achievement" component. In this study, the goal in learning was determined by the teacher, or environment (or their interaction), and thus, the participants' judgments of efficacy were in reference to this goal.

One implication of the inclusion of teacher's assistance component in this framework is that selfefficacy judgements for similar tasks varied between the three participants because of the environmental differences such as teacher's assistance. For example, Aishah's self-efficacy for writing was lower than the other participants because the teacher used questioning technique and she felt she could not respond well like her classmates who were able to respond and did better in their writing. Thus, this portrayed an environmental difference on Aishah's part. Farah also indicated how she felt unconfident when learning writing last year when she was in third former class. In this case, Farah's judgment of efficacy was lower in comparison to last year, with a different teacher and classroom. She could not internalise what her previous teacher was trying to teach and disagreed with the activity implemented which did not require her participation (interview on 16 Nov 2009).

Both examples indicated that Aishah and Farah had lower than usual "self-confidence" in their capabilities to perform a specific task depending on the environment they were in or how far they managed to be involved in the learning process. This shows that the more the participants engaged, interacted with the teacher, and especially the more they learn and the better they perform, the higher their self-efficacy. Hence, the arrow flows back to self-efficacy from learning and achievement component in the fig 2. 
Apart from that, the higher their writing self-efficacy, the more they wanted to engage in the task and think on how to solve the task. Thus, it can be concluded as well that self-efficacy can lead to more behavioural and cognitive engagement and, subsequently, to more learning and better performance. However, while engaging in the task, failure in carrying out the task withdrew low self-efficacy writer from the writing task. Meanwhile, the average and high self-efficacy writer faced the challenge and tried to find ways to solve the task given. Both writers reported that it motivated them to try even more to improve (interview on 16 Nov 2009). This study therefore found that the arrows for cognitive and behavioural engagement also flow back to selfefficacy over time as indicated by the arrow in the figure 2. Overall, all the aspects of engagement as well as learning and achievement are all reciprocally related in this study. The next section will discuss the pedagogical implication derived from this new self-efficacy framework and findings.

\section{Pedagogical Implication}

Findings in this study show that the rural learners as writers could be involved in the process of planning, drafting, revising and editing. The process of writing not only allowed them to find direction in their writing but they were able to understand the process involved in the writing of their composition too. By involving in the process, the rural learners were able to seek options and foster their own creativity to produce effective piece of composition. For instance, the learners in this study were able to write thesis statements that presented a clear stance of their essay. Therefore, the process is important in writing classroom in order to help the learners to become skilled writers. In addition, the learners should be part of the writing process as it allowed the learners to get feedback from their audience immediately. In sum, writing process approach adopted by the teacher in this study managed to help the learners to see the bigger purpose of writing that is to communicate their ideas and opinions effectively, and secondly to engage with the ideas in the text. This required a different pedagogical approach in teaching writing in Malaysian classroom. It will be more feasible if the teacher can implement writing process approach in teaching writing. Generally, Malaysian schools aimed more than twelve written works done by the learners per year. However, with process approach, it was observed that the learners in this study were able to produce less than the targeted number of essays per year. In this study, the learners managed to write seven titles of essays per year. Even though the number of essays produced in this study was fewer than the expected numbers set by the school, the quality of the written work was better in terms of vocabulary, content and grammar components. Apart from that, the learners were able to justify on how to correct their peers' writing. This was achieved through the drafting, rewriting and editing stages which derived from the writing process approach. This in a way required a change in the teacher's mindset that the quality of the essays is far more important than the quantity itself.

Besides this, different writers may approach writing differently and therefore, determining the level of assistance in teaching is important. Some writers may need more assistance than the others. Therefore, working in group is suitable as it allows the learners to interact and discuss at various levels and perhaps in a mix ability group. Findings from this study showed that high self-efficacy writer liked to control the conversation in the group discussion. Meanwhile, the low self-efficacy writer preferred to isolate herself from working in group and thus made a passive participation in the group discussion. Thus, there is a need for the teacher's intervention in group work for the learners to achieve the expert level. When necessary, it is important to split friendship group as learners working with friends can seriously impede the creation of balanced ability grouping. Rubin et. al (1994) suggested that children tend to form friendship with others of similar age, race, sex, outlook and intelligence. It is therefore sometimes necessary for the teacher to intervene if there is an imbalance of ability in a single group" (Rubin et al.. 1994:8). Therefore, it is important for the teachers to intervene if there is different writing self-efficacy level among the learners. In this study for example, the teacher allowed the learners to choose and decide their own group. As a consequence, the low self-efficacy writer tend to join her friends who were passive like her, while the high self-efficacy writer was willing to join active group and persisted longer in any activities. Here, there was an imbalance distribution of writing self-efficacy level among the learners in the group which finally affected their writing performance in the end.

\section{Conclusion}

In summing up all of these implications, it shows that findings of this study may contribute to the understanding of the process in developing rural learners' writing skills and writing self-efficacy. It gives the insight to developing writing skills, writing self-efficacy and teacher's assistance in Malaysian context. In other words, the rural learners were enhanced by giving assistance and their writing self-efficacy level actually affected how they accepted the assistance given. This indicates a need to consider learners' writing self-efficacy level in order to allow the teacher to adapt and improvise their teaching technique. This in the way gives a new perspective in teaching writing as teachers may need to consider writing self-efficacy level as part of their teaching technique. Apart from that, with the additional component that is teacher's assistance in developing rural learners' writing skills and writing self-efficacy, it contributes to a more specific self-efficacy development 
framework as it points out specifically the component that may affect the learners' writing self-efficacy. With this additional component for self-efficacy framework, it may help future researchers to understand further how a learner actually develops their writing self-efficacy via social interaction specifically.

\section{References}

[1] Linnenbrink, E.A. \& Pintrich, P.R., The role of self-efficacy beliefs in learner engagement and learning in the classroom. Reading and Writing Quarterly, 19, 2003, 119-137.

[2] Pajares, F. \& Johnson, M. J. (1995, April). The role of self-efficacy beliefs in the writing performance of entering high school learners: A path analysis. Paper presented at a symposium held during the meeting of the American Educational Research Association, San Francisco.

[3] Pajares, F., \& Valiante, G., Influence of self-efficacy on elementary learners' writing. Journal of Educational Research, 90(6), 1997, 353-364.

[4] Bandura, A. (ed), Self efficacy in changing socities (New York: Cambridge University Press, 1995).

[5] Kim, U. \& Park, Y.S., The development of Korean adolescents' psychological and behavioural make-up: The influence of family, school, friends and society. Korean Journal of Educational Psychology, 13, 1997, 99-142.

[6] Rahil Mahyuddin, Habibah Elias, Loh Sau Cheong, Muhd Fauzi Muhamad, Nooreen Noordin \& Maria Chong Abdullah, The relationship between learners' self-efficacy and their English language achievement. Jurnal Pendidik dan Pendidikan, 21, 2006, 61-71.

[7] Schunk, D.H. \& Zimmerman, B.J., Influencing children's self-efficacy and self-regulation of reading and writing through modelling. Reading and Writing Quarterly, 23, 2007, 2-25.

[8] Zimmerman, B.J \& Kitsantas, A., Acquiring writing revision and self-regulatory skill through observation and emulation. Journal of Educational and Psychology, 94, 2002, 660-668.

[9] Jarvela, S., Shifting research on motivation and cognition to an integrated approach on learning and motivation in context, in Simone Volet \& Sanna Jarvela (Eds.), Advances in learning and instruction series: Motivation in learning contexts: Theoretical advances and methodological implications (New York: Emerald Group Publishing, 2001) 3-16.

[10] Bandura, A., Self-efficacy: The exercise of control (New York: W.H. Freeman \& Company, 1997).

[11] Hidi, S \& Boscolo, P., Motivation and writing, in Charles MacArthur, Steve Graham, and Jill Fitzgerald (eds.). Handbook of writing research (New York: The Guilford Press, 2008) 144-157.

[12] Pajares, F., Self-efficacy beliefs, motivations, and achievement in writing: A review of the literature. Reading and Writing Quarterly, 19, 2003, 139-158.

[13] Zuraidah Mohamad. (1999). Self-efficacy of the primary science teachers in Malaysian primary schools in Selangor. Unpublished Master Thesis. International Islamic University Malaysia.

[14] Chew, Pay Chian, Learners' academic self-concept, and perception of teacher efficacy and teacher connectiveness, Master Dissertation, University of Malaya, 2000.

[15] Wong, Lee Lih., Perhubungan antara efikasi-kendiri dengan pencapaian Matematik pelajar tingkatan satu, Master Dissertation, University of Malaya, 2004.

[16] Wong, Mary Siew Lian, The relationship between secondary school learners' self-regulated learning strategies and self-efficacy in learning science, Ph.D Thesis, University of Malaya, 2001.

[17] Norzilah Mohd Yusof, The relationship between self-efficacy, learning styles and reading motivation of ESL learners, Master Dissertation, Universiti Sains Malaysia, 2005.

[18] Rosna Awang Hashim, The effects of state and trait worry, self-efficacy, and effort on statistics achievement of Malay and Chinese undergraduates in Malaysia: A causal modelling approach, Ph.D Thesis, University of Southern California, 1999.

[19] Mohamed Abdirahman Maalim. (2004). Learners'goal orientations, value for academic learning, self-efficacy beliefs, and use of self-regulated learning strategies. Unpublished Ph.D Thesis. International Islamic University Malaysia.

[20] Volet, S. (2001).Understanding learning and motivation in a multi-dimensional and multi cognitive-situative perspective. In Simone Volet \& Sanna Jarvela (eds.). Advances in learning and instruction series: Motivation in learning contexts: Theoretical advances and methodological implications, (pp.57-84). New York: Emerald Group Publishing.

[21] Gardner (2009). Mixed-methods studies. In Fraenkel, J.R. \& Wallen, N.E. How to design and evaluate research in education (7 ed.), (pp.555-585). United States of America: McGraw Hill Inc.

[22] Bottomley, D., Henk, W., \& Melnick, S. 1997/1998. Assessing children's views about as writers using the writer self perception scale. The Reading Teacher 51(4): 286-291.

[23] Wiersma, W.\& Jurs, S.G. (2005). Research methods in education: An introduction ( $8^{\text {th }}$ Edition). New York: Pearson Education, Inc.

[24] Wang, C \& Pape, S.J. (2005). A probe into three Chinese boys' self-efficacy beliefs learning English as a second language. Journal of Research in Childhood Education, 21 (4), 364-387.

[25] Neuman, W.L. 2003. Social research methods: Qualitative and quantitative approaches (Fifth Edition). New York: Allyn \& Bacon.

[26] Siti Hamim Stapa. (1998). The process approach to ESL writing. UKM Bangi: Faculty of Language Studies, Universiti Kebangsaan Malaysia.

[27] Duke, C.R. (1983). Writing through sequence: A process approach. Boston: Little, Brown and Company.

[28] Earl, C.B \& Zimmerman, C. (2003). The reading/writing connection. New York: Longman.

[29] McCarthey, S., Garcia, G.E, Lopez-Velasquez, A.M, Lin, S. Guo, Y.H. 2004. Understanding writing contexts for English language learners. Research in the Teaching of English 38(4): 351-394.

[30] Smith, A. 1997. Understanding children's development : A New Zealand perspective. ( $3^{\text {rd }}$ ed.). New Zealand : Bridget Williams Books Ltd.

[31] Rubin, K.H., Lynch, D., Coplan, R., Rose-Krasnor, L. \& Booth, C.L. 1994. "Birds of a feather...”: Behavioural concordance and preferential personal attraction in children. Child Development 64: 1778-1785. 